Prof. F. A. Forel and Captain Marshall Hall, has appointed a committee to investigate the variations of glaciers. Represen. tatives of various countries are appointed. Prof. Forel and Dr. L. du Pasquier will have charge of this committee, the expenses of which will be defrayed by Prince Roland Bonaparte, the representative of France on the committee.

Dr. A. Rothpletz spoke on "Overthrusts and their methodical investigation"; MI. Steinmann gave a note on the "Extent of the Indo.Pacific Cretaceous region." The Section of Stratigraphy and Palæontology, presided over by M. Gaudry, heard papers by Prof. Hull, by MII. Sacco, Fallot, MayerEymar, Depéret; on "Tertiary strata and their classifica tion," by Profs. Steinmann and Boehm, and by M. Pavlov on "Cretaceous strata"; by M. Kilian, on "the limit of the Jurassic and Cretaceous systems" ; and by M. Stephanescu, on the "Fossil camel in Roumania." The other sections were Mineralogy and Petrography, M. Michel Levy presiding; and Applied Geology, Dr. Hauchecorne presiding. At the Mineralogy and Petrography Section several papers were read; among others, one on the petrography of Attica, by Prof. Lepsius, on grorudites and tingnaites, by Prof. Brögger. Prof. Groth showed a simple apparatus for demonstrating the direcvion of the vibrations in biaxial crystals.

An interesting interlude was formed at the meeting on August $3 \mathrm{I}$, by the presentation to Geheimrath Beyrich of a magnificent wreath of Alpine flowers made in the name of the assembled geologists. The day was the eightieth anniversary of Beyrich's birth, and Prof. Heim expressed the feeling; of all present in the warm words of congratulation and appreciation which he addressed to the veteran geologist. Not less touch. ing was the reply of the Geheimrath to the graceful token of love and respect from his colleagues of all European nations.

Space will not permit a description of the excellent exhibition of maps, photographs, models, and specimens in connection with the Congress. Exhibits had been sent from all countries. Also the great collection of the Zuirich museums was an attraction in itself, and Prof. Heim was untiring in his efforts that all the guests should see all and even more than all which they had hoped to observe. The new geological map of Switzerland, scale I : 500,000 , prepared by Heim and Schmidt, won the admiration of all, and together with the geological guide-book of the excursions published by the organisation committee, will remain as a valuable, lasting witness of the enterprise and energy displayed by Switzerland and her professors on the occasion of the sixth Congress.

It is rather unfortunate that the weather, which had been the best of summer weather during the excursions in the Jura Mountains previous to the meeting, and throughout the meeting itself, should have broken just as the excursions into the Alps began. Rain and mist undoubtedly bid fair to mar the enjoyment and lessen the benefits. From September 17 to 23 an excursion will be conducted by Profs. Penck, Brückner, and du Pasquier, for the study of glacial appearances in the Alps. A special paper has been published uy these three geologists, more especially with a view to this excursion, but also of general interest, entitled "The Glacial System of the Alps."

The seventh meeting of the International Geslogical Congress will be held in 1897 at St. Petersburg. 'The geological tours proposed were shown in a map of Russia exhibited during the Congress. An excursion across Russia and the Ural MIountains will precede the St. Pelersburg meeting, and one is arranged to be undertaken to the Caucasus and the Caspian Sea at the close of the meeting. 'The Czar, it is said, has invited the Congress to St. Petersburg, and has already subscribed 30,000 roubles to defray in part the expenses of the Congress.

\section{THE INTERNATIONAL CONGRESS OF HYGIENE.}

THE International Congress of Hygiene and Demography, recently held at Budapest, does not appear to have been very successful from a scientific point of view. The medical journals say that serious work was impossible at the Congress, owing to the numerous social amusements and entertainments provided for the members. This opinion is borne out in a report in the Times, to which we are indebted for the following notice.

Our contemporary remarks that unless some sweeping reforms are introduced into the procedure of the Congress

$$
\text { No. I 299, vOL. 50] }
$$

the same loss of prestige which has reduced other similar institutions to impotence or extinction seems certain to overtake it. The Congress appears to have ended in a chootic confusion for which the word fiasco is none too strong, and the principal reasons for this unforiunate state of things are said to be (I) an overwhelming development of what may be called the picnic element ; (2) an abuse of the system of passing sectional resolutions; (3) the superabundance of papers.

But, in spite of the confusion and turmoil resulting from the foregoing defects of procedure, an abundance of valuable material was brought forward at the Congress, some of which might, under more favourable circumstances, have been foccsied into a shape which would exercise a real influence on practical questions of public health and social economy. Much sound and useful work, for instance, was done upon such question 3 as the housing of the working classes, the influence of dwelling; and occupations upon health, the movements of population, and especially the townward migration, upon the condition of the insane, upon school hygiene, practical sanitation, and many others. The real scientific life of the Congress, however, lay in the department dealing with infectious disease and bacteriology. Here three crowded meeting; took place on three successive days to discuss the following questions:-(I) Immunity from infectious disease ; (2) diphtheria ; (3) cholera.

The first of these is of great practical importance, because the future of medicine, from the present bacteriological point of view, lies in solving the problem of immunity. According to one school immunity is effected by certain cells (leucocytes) which eat up the germs, and are therefore called phagocytes. This fascinating theory was introduced a few years ago by M. Metchnikoff, the eminent cbief of the Pasteur Institute in Paris ; but the balance of opinion seems to be turning against it in favour of the theory that the germs are mainly destrojed by certain chemical substances contained in the watery part of the blood. Prof. Buchner, of Munich, is a prominent supporter of this theory, and his paper, read at the Congress, summarises the latest views on the subject. "The natural capacity for resistance to infection (the so-called natural immunity) rests on essentially different conditions and causes from the artificial or acquired immunity. The former rests on the one side upon the bactericidal activity of a substance called Alexine, which is secreted by the organism, on the other by a natural insusceptibility of the cells and tissues of the body to particular bacterial poisons. The leucocytes play an important part in the natural protection of the organism, not, however, as phagocytes, but through the action of substances secreted by them. Acquired immunity, upon the other hand, rests on the presence of modified bacterial products, the so.called Antitoxine, either in the blood or in the tissues of the body." M. Metchnikoff defended his theory of phagocytosis with great vivacity, but the other leading bacteriologists present, including Prof. Roux, of Paris, were on the other side. The debate marks a step in the advance of knowledge, though not a very decided one.

The morning devoted to diphtheria was the central point of the Congress. An overflowing and animated audience attended the meeting. This fearful disease is the most burning question in the medical world at the present time, partly because of its alarming increase, and more recently because of the hopes entertained of the new method of treatment, derived from bacteriological research. Prof. Löffler, the euninent discoverer of the diphtheria bacillus, opened the proceedings by reading the German report, which recommended "immediate bacteriological examination of all suspected cases; notification to the police of all bacteriologically determined cases and of all doubt. ful ones; isolation of every case; protective inoculation with serum of persons about the invalid, particularly children; extension of this principle as far as possible in families and schools; disinfection, keeping of convalescents apart until the bacillus has disappeared."

Similar drastic measures were recommended in the French report. The English report did not suggest any practical measures for dealing with the evil, but pleaded for more careful study, and more accurate knowledge of its causes and conditions. The Danish, Hungarian, Swedish, and Swiss reports also pleaded for further investigation. It is much to be regretted that the Congress could not find time to formulate some, and carefully-weighed, conclusions on this important matter.

In a debate on chalera, which followed in the same section, Prof. Max Gruber said, at the commencement of his address, that the bacteriology of the disease is by no means so simple 
as was once supposed; "the deeper investigation goes the greater the difficulties that rise up before us." Continuing, the Times reports him as remarking that the result of his own investigations had brought him to doubt the specific cha. racter of the cholera bacillus. "The question," he said. "is in this strange position-that, while we know with certuinty that the vibrios which appear in cholera are the cause of the symptoms of the disease, we do not know for certain that these vibrios are of a distinct species. We cannot say for certain whether in all cases of true cholera they belong to a single species or to several, whether they are distinct from our own native vibrios or not." He was inclined to think they were not distinct, and propounded a quite new theory to the effect that these native and harmless vibrios take on an injurious character and give rise to cholera when some other at present undis. covered germ is introduced; for it is certain that cholera is introduced, and yet apparently the germs are here all the time. II. Metchnikoff, on the other hand, defended the specific character of the cholera vibrio, but admitted that it was not everything. It is frequently present, and yet does no harm. To explain this he has invented yet another theory, very curious and rich in appalling possibilities. The cholera germ, he thinks, is only powerfol for evil when the native bacilli of the human interior, the flora of the stomach and intestines, as he quaintly calls them, are favourable to its growth. It is pointed out by our contemporary that these utterances are interesting as marking a distinct change of front and a distinct advance in knowledge. Bacteriologists, as the result of their own investi. gations, are beginning to come into line with the position long maintained by other observers, who rearhed their conclusions by the old method of studying the facts of epidemic disease. The germ is, no doubt, the cause of the disease, but it alone will not suffice. Its effects depend upon the conditions in which it is placed, upon its environment; it must have a favourable soil in which to grow, or it changes into a harm. less variety. And this bacteriological doctrine has an imporlant bearing on the encouragement of hygiene, for it helps to to understand more precisely how hygienic measures isork in rendering the soil unfavourable to the growth of the injurious micro-organisms.

\section{SCIENCE IN THE MEDICAL SCHOOLS.}

THE students' number of the Lancet furnishes some interesting information upon the curricula of the medical schools of Great Britain. With the idea of seeing how far science instruction in subjects not purely medical is provided in these schools, we have prepared the subjoined table, from lists given in our contemporary, of classes to be held during the session

\section{Metropolitan diedical Schools.}

St. Bartholomew's Itospital Charing Cross Hospital and Colle St. George's Hospital ... ... Guy's Hospital King's College IIospital London Hospital

St. Mary's Hospital

Middlesex Hospital

St. Thomas's Hoipital and i. ...

University College and Hospital..

Westminster Hospital

\section{Provincial Medical Sciools.}

University of Durham College of Medicine

\section{University College, Liverpool}

Owens College School of Mledicine $\quad \ldots \quad \ldots$

Sheffield School of Medicine $\quad \ldots \quad$...

IIason College

University College, Bristol

Cambridge University

Oxford University

Yorkshire College, Leeds .

University College, Cardifi

\section{Medical Schools of Scotgaid.}

Aberdeen University

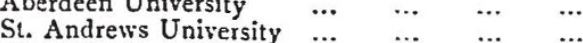
$\begin{array}{lllll}\text { Edinburgh University } & \ldots & \ldots & \ldots & \ldots\end{array}$ Glasgow University

St. AIungo's College and Scirool of IIedicine Anderson's College, Glasgow $\quad \ldots \quad$, ... $\quad \ldots$


University College, Dundee $\quad \ldots . \quad \ldots . . \ldots$

\section{Medical Schools of Irelain.}

Dublin University ...

Dublin Royal Cnllege of Surgeons

Catholic University, Dublin

Queen's College, Belfast ...

Queen's College, Cork

Queen's Colleg'e, Galway ...
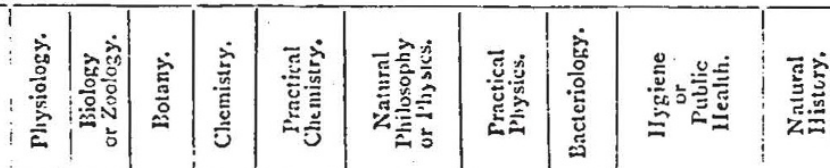